УДК: 911.2:551.2x

МРНТИ: 39.19 .31

DOI 10.37238/1680-0761.2021.84(4).46

\author{
${ }^{1}$ Петрищев В.П.*, ${ }^{2}$ Кожевникова Н.В. \\ ${ }^{1}$ ФГБОУ ВО «Оренбургский государственный университет», \\ ФГБУН «Институт степи УрО РАН» \\ ${ }^{2}$ ФГБОУ ВО «Оренбургский государственный университет» \\ *Автор-корреспондент: wadpetr@mail.ru \\ E-mail:wadpetr@mail.ru, knv0405@mail.ru
}

\title{
АНАЛИЗ ФАКТОРОВ ФОРМИРОВАНИЯ ЛАНДШАФТНЫХ ГЕОСИСТЕМ СОЛЯНОКУПОЛЬНЫХ ОБЛАСТЕЙ КАК ОСНОВА ПОСТРОЕНИЯ МОДЕЛИ ГАРМОНИЧНОГО ПРИРОДОПОЛЬЗОВАНИЯ
}

\begin{abstract}
Аннотация. Современные взгляды на солянокупольный ландмафтогенез проявляются в первую очередь в выявлении региональных моделей взаимодействия соляной тектоники с различными факторами экзогенеза, что обуславливает крайне высокое морфоструктурное своеобразие ландшафтных геосистем. В настоящее время наиболее важные научные направления в отношении солянокупольного ландшафтогенеза касаются четырех основных направлений. Первое касается оригинальных идей и концепциии с области солянокупольного тектогенеза, что имеет неоченимое значение для построения моделей формирования ландшафтов над соляными куполами. Второе связано с разработкой проблем геоморфологического проявления солянокупольных прочессов. Третье направление собственно ландшафтоведческое. Оно объединяет исследования, отражаюшие ландшафтные проявления соляных структур. Четвертый раздел отражает прикладные аспекты использования солянокупольных геосистем как объектов недропользования, так и в рекреационно-туристических иелях и природоохранных иелях. Особое внимание при изучении ландшафтов, связанных с эвапоритами, связано с высокой вероятностью концентрачии в них благородных металлов. Данное направление является перспективным в пределах Прикаспийско-Предуральского слянокупольного бассейна, в т.ч. в пределах Республики Казахстан. Также малоизвестным фактом является мелиорирующая роль соляной тектоники. Соляные купола Прикаспийской впадины являются основой организации многочисленных особо охраняемых природных территорий, в т.ч. в Республике Казахстан.

Ключевые слова: соляная тектоника, галокинез, диапир, кепрок, эвапоритовая экструзия, морфоструктурные типы рельефа, соляной карст, ландшафтные геосистемы, региональные модели ландшафтогенеза, оруденение, мелиорачия, геопарк, спелеотерапия, минеральные грязи.
\end{abstract}

\section{Введение}

Соляная тектоника как один вариантов псевдотектогенеза обладает важной особенностью - прорывая надсолевые породы, соляные диапиры преобразуют ландшафтную структуру, активизируя межкомпонентные взаимодействия за счет включения в процесс ландшафтогенеза как соляного ядра, так и всего комплекса глубоко залегавших 
геологических пород, оказавшихся на поверхности. Геологические аномалии, которыми по существу являются солянокупольные поднятия, инициируют целый комплекс прочих аномалий, которые могут взаимодействовать и взаимообуславливаться. К числу таких проявлений соляного тектогенеза следует отнести гидрогеологические и гидрологические, геоморфологические, климатические, гео- и гидрогеохимические, аномалии почв и растительности, которые складываются в динамические комплексы природных компонентов, именуемых солянокупольными ландшафтами. Анализ морфоструктуры солянокупольных ландшафтов показывает, что соляной тектогенез дестабилизируя природные компоненты, является ведущим фактором ландшафтогенеза Прикаспийской и Примексиканской низменностей, равнин Приуралья, Восточного Техаса, Южной Якутии, гор Южного Ирана (Загрос) и Таджикистана (Кулябская долина). Более 5\% земной поверхности относится к солянокупольным бассейнам, в пределах которых располагается около 4 тыс. соляных структур.

Анализ особенностей проявления соляной тектоники в ландшафтах различных регионов мира показал, что формирование специфических свойств геосистем при росте соляного диапира происходит постепенно, поэтапно. Данный процесс получил название «солянокупольный ландшафтогенез». Вершиной этого процесса, когда соляное ядро выходит на поверхность, является экструзивный (кульминационный) этап. В пределах данного этапа проявляется весь спектр разнообразных аномальных черт нового ландшафта, определяющих его резкое несходство с окружающими природными комплексами.

Солянокупольные структуры являются одним из наиболее важных объектов недропользования и играют большую роль в формировании природно-ресурсного потенциала. Многообразие использования соляных структур в качестве месторождений каменной и калийных солей, гипсов, строительных материалов, различных минералов, хранилищ топлива и радиоактивных отходов, а также их значение в качестве коллекторов для залежей нефти и природного газа обусловливает значительное количество аварий и катастроф на горных выработках, образование глубоко нарушенных техногеосистем, воздействие на городские территории. Вместе с тем солянокупольные ландшафты концентрируют высокий рекреационный и бальнеологический потенциал за счет формирования геосистем c уникальными свойствами литофацильных образований (минеральные грязи), природных вод (природные рассолы), а также воздушной среды в подземных выработках (спелеотерапия).

На сегодня имеется стремление вовлекать в разработку нетрадиционные типы месторождений в пределах соляных структур, такие как новый для Урала тип нетрадиционного благороднометального оруденения в соляных отложениях [1, 2]. В последние годы именно с такими нетрадиционными месторождениями металлических руд в кепроках связаны открытие и введение в оборот важных объектов недропользования в ряде стран мира.

Велико значение солянокупольных ландшафтов в формировании охраняемых природных территорий - национальных парков и памятников природы, в первую очередь за счет проявления на поверхности соляного и сульфатного карста и выхода на поверхность разнообразных надсолевых отложений.

Соляная тектоника выполняет мелиорирующую роль по отношению к сельскохозяйственным угодьям - в результате тектонического подъема происходит рассоление солонцов и солончаков (Прикаспийская низменность), осушение ранее заболоченных земель (Примексиканская низменность).

Многообразие и активность межсредовых и межкомпонентных связей, инициируемых соляной тектоникой, обширность районов ее распространения ставят ее в один ряд с крупными природными силами, изменяющими облик Земли. 

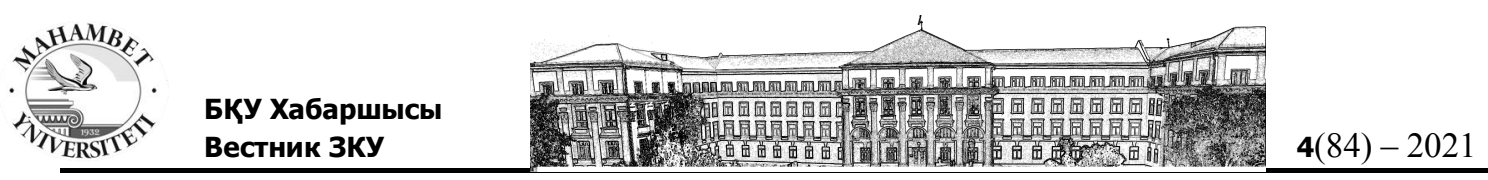

В связи с выше изложенным значимость соляной тектоники состоит в постиндустриальном использовании отработанных соляных месторождений, оценке возможностей самовосстановления техногенных ландшафтов соляных месторождений, фундаментальных исследованиях широтно-зональной ординации солянокупольных ландшафтов России, продвижении собственных исследований в странах с передовыми исследованиями в области соляной тектоники и форм ее выражения в геоморфологических формах и ландшафтных системах.

Различные направления изучения особенностей поверхностного проявления соляной тектоники в настоящее время пользуется популярностью в различных странах мира. В зависимости от размещения солянокупольных бассейнов и природно-климатических зон глубина и виды таких исследований могут отличаться.

Современные публикации, так или иначе затрагивающие проблемы воздействия галокинеза на различные природные компоненты, могут быть разделены на четыре группы:

1. Научные публикации, в которых отражены преимущественно структурнотектонические особенности проявления галокинеза, причем как на общем, так и на региональном уровне. Сюда относятся работы выдающихся отечественных геологовтектонистов - Ю.А. Косыгина [3], В.Я. Аврова [4], Г.Е.А. Айзенштадта [5], А.А. Богданова [6], В.С. Конищева [7], В.И. Китыка [8], А.А. Свиточ [9]. Среди зарубежных авторов сюда следует отнести ученых США (Jackson M. [10], Collins E. [11], Kupfer D. [12],Seni S. [10] и др.), Европы (Talbot C. [13]).

Среди современных авторов следует выделить статьи И.И.Чайковского (Пермский научный центр УрО РАН), обобщившего все региональные модели солянокупольного тектогенеза, что имеет неоценимое значение для построения моделей формирования ландшафтов над соляными куполами с участием различных физико-географических факторов [14]. По масштабам структурно-динамического рассмотрения соляной тектоники как мирового фактора трансформации поверхностных слоев литосферы необходимо выделить публикации Г.А.Беленицкой (ВСЕГЕИ), представившей оригинальные идеи и концепции, комплексно отражающие формирование соляных структур в различных регионах мира [15]. Большое значение имеют публикации А.В.Самойловой [16] (Институт проблем нефти и газа РАН), Ю.В. Казанцева [17], Т.Т. Казанцевой [17], В.М. Горожанина [18], Е.Н. Горожаниной [18] (Институт геологии Уфимского научного центра РАН).

Из зарубежных авторов необходимо особо выделить работы Майкла Хьюдека (Michael Hudec) [19], которому принадлежат крупные мировые обзоры проявления соляной тектоники (в соавторстве с умершим Мартином Джексоном). Достаточно существенным недостатком обзоров является отсутствие сведений по солянокупольным бассейнам на территории России, что обсуждалось на личной встрече в 2017 году в Остине.

2. Разработка проблем геоморфологического проявления солянокупольных процессов.

Здесь следует выделить также работы выдающихся отечественных геоморфологов Николаев Н.И. [20], Рождественский А.П. [21], Мещеряков Ю.А. [22], Брицына М.П. [22], Аристархова Л.Б. [23], Журавлев В.С. [24], Сладкопевцев С.А. [25], Благоволин Н.С. [26] и другие, многие из которых работали над солянокупольными морфоструктурами в Прикаспийской впадине.

В эту группу относятся крупные работы по соляному карсту - А.И. Дзенс-Литовский [27], Короткевич Г.В [28]. За рубежом крупные обобщения в области карстового рельефа в пределах солянокупольных поднятий проведены Warren J. К. [29], который по нашей оценке является крупнейшим специалистом как в отношении соляного карста, так и прикладных аспектов использования солянокупольных структур. Чрезвычайно значимы для геоморфологического моделирования солянокупольных процессов как современные работы W.Autin [30], так и самые ранние работы Lobeck A. [31]. Более разнообразны исследования в настоящее время, проводимые в Южном и Центральном Иране, где основное внимание 
исследователей обращено на т.н. соляные «глетчеры» (экструзии) и известны достаточно интересные геоморфологические классификации (Jahani S., Callot J.-P., Frizon de Lamotte D.) [32]. В 1999-2011 гг. очень интересными были карстологические исследования, проведенные чешскими учеными в Южном Иране (Filippi M., Bruthans J., Palatinus L., Bosak P.) [33]. Результатом стала серия серьезных обобщений в области галогенного карста на открытых диапирах, представляющие большую ценность для теории солянокупольного ландшафтогенеза. В Германии изучение соляной тектоники связано со структурногеологическими нарушениями и обследованием отдельных геоморфологических форм (Люнебург, Jaritz W., [34]). Среди новых работ, раскрывающих структурногеоморфологические аспекты соляной тектоники следует выделить статью В.П. Чичагова "Геодинамика солянокупольных структур района Баскучак - Большое Богдо" (Астраханский вестник экологического образования, 2014) [35], в которой раскрывается один из «феноменов» соляной тектоники - несоответствие между скоростью роста соляного диапира и рельефом. В статье Зеленковского П.С. и Куриленко В.В. Природно-техногенная система соляного озера Баскунчак и особенности эксплуатации её ресурсов (Вестник СанктПетербургского университета, 2013) - раскрываются особенности функционирования техногеосистемы, сложившейся на месте добычи озерной соли на озере Баскунчак [36]. Следует отметить активизацию в последнее время геолого-геоморфологических исследований открытых соляных структур в Южном и Центральном Иране. При этом выделяются научные работы иранских ученых (M.Zarei, E. Raeisi и др.), детально рассматривающие модели формирования соляных экструзий и карстовых полей [37].

3. Исследования, отражающие ландшафтные исследования проявления соляных структур. Несмотря на достаточно большое количество публикаций в отношении различных аспектов воздействия солянокупольных структур на поверхность хотелось бы выделить одну, небольшую по объему, но которая на наш взгляд раскрывает основные черты ландшафтных «феноменов» соляной тектоники - Николаев В.А., Копыл И.В., Пичугина Н.В. Ландшафтный феномен солянокупольной тектоники в полупустынном Приэльтонье. Вестн. Моск. ун-та, сер. 5 "География", № 2, 1998, с. 35-39 [38].

Данное направление исследований активизировалось в последние 5 лет в Западном Казахстане в связи с организации национального парка Индер (К.М.Ахмеденов) [39].

4. Прикладные аспекты использования солянокупольных геосистем как объектов недропользования, так и в рекреационно-туристических целях и природоохранных целях.

Среди современных авторов следует отметить работы Синякова В.Н., Беляевой Ю.Л., Кузнецовой С.В. [40] в отношении геоэкологических проблем использования ресурсов соляных куполов, Мозера С.Н. [41], Никитина И.И. [42] - в отношении геотектонических деформации, инициированных в ходе добычи соли.

В США (Луизиана и Восточный Техас) делается акцент на геотектонических особенностях соляных диапиров и их практическом использовании в соледобыче и в качестве резервуаров. Следует отметить, что ученые США, специализирующиеся как на геологических и структурно-тектонических аспектах, так и на ландшафтногеоморфологических аспектах проявления соляной тектоники в Луизиане, исходят исключительно из практических аспектов использования солянокупольных структур. Это касается оценок стабильности работы соляных шахт на выдающихся в отношении ландшафтного разнообразия солянокупольных «островах» Луизианы.

В Испании анализ воздействия соляной тектоники связан с изучением техногенного карста в районах добычи соли (купол Кардона, Каталония).

В отношении природоохранных и туристско-рекреационных аспектов нужно выделить научные работы Цапиной Н.Л. (МГУ) [43], И.В.Головачева в отношении Богдинско-Баскунчакского солянокупольного района в России, Индерского и МалоБогдинско-Бишчохинского солянокупольных районов в Казахстане [44]. 


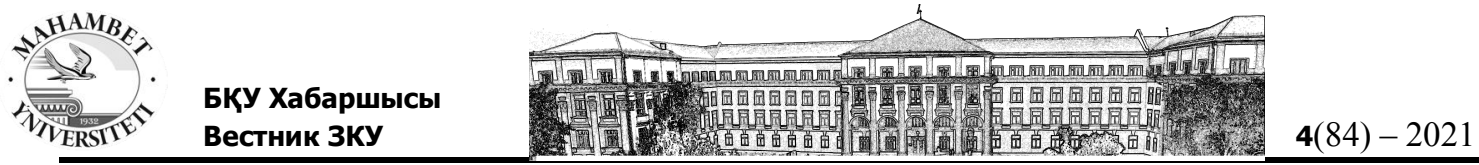

Работа выполнена в рамках темь НИР Оренбургского государственного университета "Экологический мониторинг территорий в целях охраны и раџионального использования природных ресурсов" и темы НИР Института степи УрО РАН «Степи России: ландшафтно-экологические основы устойчивого развития, обоснование природоподобных технологий в условиях природных и антропогенных изменений окружающей среды» (ГР АAAA-A17-117012610022-5).

\section{ЛИТЕРАТУРА}

[1] Сметанников А. Ф. Содержание и распределение $\mathrm{Au}, \mathrm{Ag}$ и Pt-металлов в сильвинитах Верхнекамского месторождения /Сметанников А. Ф., Кудряшов А. И.// Геохимия. - 1995. № 9. - С. 1348-1351.

[2] Золоев К. К. Платинометалльное оруденение в геологических комплексах Среднего Урала / Золоев К. К., Мардиросьян А. Н.// - Екатеринбург: Уралгеолфонд, 2000. 260 с.

[3] Косыгин Ю.А. Соляная тектоника платформенных областей. / Косыгин Ю.А.// М.-Л., Гостоптехиздат, 1950, 248 с.

[4] Авров В.Я. О генезисе солянокупольных структур Прикаспийской впадины и основных принципах формирования в них нефтяных и газовых месторождений. /Условия образования и особенности нефтегазоносности солянокупольных структур. Материалы Первого симпозиума. / Авров В.Я. // - Львов, 1964 г. Киев: Наукова думка. - С.105-111.

[5] Айзенштадт Г.Е.-А. Основные закономерности формирования соляных куполов и залежей нефти Прикаспийской впадины. Условия образования и особенности нефтегазоносности солянокупольных структур./ Айзенштадт Г.Е.-А. // Материалы Первого симпозиума. Львов, 1964 г. Киев: Наукова думка. - С.58-67.

[6] Богданов А.А. Основы геологического строения Каировского нефтяного месторождения / Богданов А.А.// Нефтяное хозяйство, 1934, № 2, - С. 20-23.

[7] Конищев В.С. Сравнительная тектоника областей галокинеза древних платформ. / Конищев В.С. Под ред.Р.Г.Гарецкого. - Мн.: Наука и техника, 1984. - 190 с.

[8] Китык В.И. Соляная тектоника Днепровско-Донецкой впадины./ Китык В.И. // Киев: Наук. думка, 1970, 203 с.

[9] Свиточ А.А. Некоторые черты строения, развития, и формирования соляной структуры Прикаспийской впадины. /Тектоника и нефтегазоносность солянокупольных областей СССР. Материалы III Всесоюзного симозиума по изучению территорий развития соляной тектоники в пределах СССР, проходившего в Алма-Ате 21-25 апреля 1969 г. Свиточ А.А. // Алма-Ата: Изд-во "Наука" Казахской ССР, 1973. - с.46-53.

[10] Jackson M.P.A., Seni S.J. Atlas of salt domes in the East Texas basin. Austin, Texas: The University of Texas, 1984. - 102 p.

[11] Collins E.W. Surfical evidence of tectonic activity and erosion rates, Palestine, Keechi, and Oakwood salt domes, East Texas. /Geological Circular 82-3. Bureau of Economic Geology. Austin, Texas, 1982. - 40 p.

[12] Kupfer D.H. Structure of Salt in Gulf Coast Domes. /Fifth International Symposium on Salt-Northern Ohio Geological Society. 1981. S. 143-151.

[13] Talbot C., Aftabi P. Geology and models of salt extrusion at Qum Kuh, Central Iran. / Journal of the Geological Society, London. Vol. 161, 2004, pp. 321-334.

[14] Чайковский И.И. Типизация основных механизмов соляной тектоники мира: Верхнекамское месторождение как эталон многоэтапного гравитационного скольжения / Чайковский И.И. // Вестник Пермского научного центра. 2013. №1. С. 18-37.

[15] Беленицкая Г.А. Мертвое море: геология, происхождение, мифы. Часть 2. Происхождение и история развития солей, диапиров и рассолов Мертвого моря / Беленицкая Г.А. // Пространство и Время. 2013. № 3(13). - С. 130-144. 


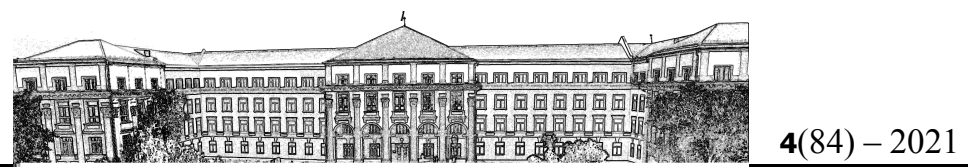

[16] Самойлова А.В. Обрядчиков О.С. Влияние соляной тектоники на общие закономерности образования залежей нефти и газа в восточной и южной частях Прикаспийской впадины. / Самойлова А.В., // Геология, геофизика и разработка нефтяных и газовых месторождений. 2008. № 2. С. 18-20.

[17] Казанцев Ю.В. О механизме соляной складчатости в Предуральском, Прикаспийском и Преддонецком прогибах. / Казанцев Ю.В., Казанцева Т.Т. // Геологический сборник. 2007. № 6. - С. 68-73.

[18] Горожанин В.М. Критерии прогнозирования месторождений нефти и газа в областях с соляно-купольной тектоникой (на примере Прикаспия и юга Предуральского прогиба)./ Горожанин В.М., Горожанина Е.Н. // Геология, полезные ископаемые и проблемы геоэкологии Башкортостана, Урала и сопредельных территорий. 2010. № 8. С. 198-201.

[19] Hudec, M. R. The Salt Mine: A Digital Atlas of Salt Tectonics / M. R. Hudec, M. P. A. Jackson. - Texas: Bureau of Economic Geology, 2011. - 305 p.

[20] Николаев Н.И. Неотектоника и ее выражение в структуре и рельефе территории СССР. / Николаев Н.И. // - М., Госгеолтехиздат, 1962, 392 с.

[21] Рождественский А.П. Новейшая тектоника и развитие рельефа Южного Приуралья / Рождественский А.П. // - М., Наука, 1971, 304 с.

[22] Мещеряков Ю.А. Геоморфологические данные о новейших тектонических движениях в Прикаспийской низменности. / Геоморфологические исследования в Прикаспийской низменности / Мещеряков Ю.А., Брицына М.П. // Изд. АН СССР, М., 1954, с. $5-46$.

[23] Аристархова Л.Б. Геоморфологические исследования при поисках нефти и газа./ Аристархова Л.Б. // - М., Изд-во МГУ, 1979, 152 с.

[24] Журавлев В.С. Геоморфологические признаки вдавленных компенсационных мульд Прикаспийской впадины. / Геоморфологический анализ при геологических исследованиях в Прикаспийской впадине (методы и результаты исследований). / Журавлев В.С. // Под ред. Л.Б.Аристарховой. - М.: Изд-во МГУ, 1968. - с. 77-86.

[25] Сладкопевцев С.А. Геоморфологический анализ как метод детализации строения и тектонического развития солянокупольных структур западной части Подуральского плато. /Геоморфологические методы при нефтегазопоисковых работах. / Сладкопевцев С.А. // - М., "Недра", 1966. - с.101-103.

[26] Благоволин Н.С. Роль соляной тектоники и грязевого вулканизма в восходящем массопереносе и рельефообразовании / Благоволин Н.С. // Геоморфология. 1985. № 2. - С. $17-27$.

[27] Дзенс-Литовский А.И. Соляной карст СССР. / Дзенс-Литовский А.И. // - Л., Недра, 1966, 168 с.

[28] Короткевич Г.В. Соляной карст / Короткевич Г.В. // Л., Недра, 1970, 256 с.

[29] Warren J. Evaporites: Sediments, Resources and Hydrocarbons. Berlin Heidelberg: Springer-Verlag, 2006. $1036 \mathrm{p}$.

[30] Autin W.J. Landscape evolution of the Five Islands of south Lousiana: scientific policy and salt dome utilization and management. //Geomorphology. 2002. - V.47. P.227-244.

[31] Lobeck A.K. Geomorphology. An Introduction to the Study of Landscapes. New York - London:McGraw-Hill Book Company. 1939. P. 512-517.

[32] Jahani S., Callot J.-P., Frizon de Lamotte D., Letouzey J., Leturmy P. The salt diapirs of the Eastern Fars Province (Zagros, Iran): A Brief Outline of their Past and Present // Thrust belts and foreland basins, frontiers in Earth sciences. Ed. By O. Lacombe, J. Lavé, F. Roure, J. Vergés. Berlin, Heidelberg, 2007. P. 289-308.

[33] Filippi M., Bruthans J., Palatinus L., Zare M. and Asadi N. Secondary halite deposits in the Iranian salt karst: general description and origin. //International Journal of Speleology, 2011. No 40 (2), pp.141-162. 
[34] Jaritz W. Zur Entstehung der Salzstrukture Nordwestdeutchlands./Geologische jahrbush. Reihe A, Heft 10. Hannover 1973. 78 S.

[35] Чичагов В.П. Геодинамика солянокупольных структур района Баскучак Большое Богдо / Чичагов В.П. // Астраханский вестник экологического образования. 2014. № 4 (30). C. 24-36.

[36] Куриленко, В. В., Месторождение минеральных солей оз. Баскунчак: геология, особенности современного соленакопления, механизмы природо- и недропользования / В. В. Куриленко, П. С. Зеленковский // Вестник СПбГУ. Серия 7. Геология, география. - 2008. - № 3. - C. 17-32.

[37] Zarei M., Raeisi E., Talbot C. Karst development on a mobile substrate: Konarsiah salt extrusion, Iran. // Geological Magazine, Cambridge University Press, 2012, No 149 (3), pp. 412422.

[38] Николаев В.А., Копыл И.В., Пичугина Н.В. Ландшафтный феномен солянокупольной тектоники в полупустынном Приэльтонье. Вестн. Моск. ун-та, сер. 5 "География", № 2, 1998, с. 35-39.

[39] Ахмеденов К.М Природа Западного Казахстана: объекты природного наследия: монография. Уральск: РИЦ ЗКГУ им. М.Утемисова, 2019. - 250 с.

[40] Синяков В.Н., Беляева Ю.Л., Кузнецова С.В. Инженерно-геологические и геоэкологические проблемы строительства современных полигонов хранения твердых бытовых отходов в Западном Прикаспии. М.: высшая школа, 2004. - 220 с.

[41] Мозер С.П. Обоснование рациональных параметров технологии разработки каменной соли на месторождениях купольного типа: диссертация ... кандидата технических наук: 25.00.22. Санкт-Петербург, 2004. с.25-34.

[42] Никитин И.И., Русскин Г.А. Образование и исчезновение озера Развал (г.СольИлецк) // Изд. Всесоюз. геогр. общ-ва, т.113, вып.2, 1981, с. 163-166.

[43] Цапина Н. Л. Оптимизация особо охраняемых природных территорий в окрестностях озера Баскунчак.//Проблемы региональной экологии. -2010. -№ 1. -С. 118-123.

[44] Головачев И.В. Карст и пещеры Северного Прикаспия./ И.В. Головачев. Астрахань: издательский дом «Астраханский университет», 2010. - 215 с.

\section{REFERENCES}

[1] Smetannikov, A. F. \& Kudrjashov, A. I. (1995). Soderzhanie i raspredelenie Au, Ag i Pt-metallov v sil'vinitah Verhnekamskogo mestorozhdenija. [Content and distribution of $\mathrm{Au}, \mathrm{Ag}$ and Pt metals in silvinites of the Verkhnekamskoye deposit] Geohimija - Geochemistry. 9, 13481351. [in Russian].

[2] Zoloev, K. K. \& Mardiros'jan, A. N. (2000). Platinometall'noe orudenenie v geologicheskih kompleksah Srednego Urala [Platinum-metal mineralization in geological complexes of the Middle Urals] Ekaterinburg: Uralgeolfond, 260. [in Russian].

[3] Kosygin, Ju.A. (1950). Soljanaja tektonika platformennyh oblastej [Salt tectonics of platform areas] M.-L., Gostoptehizdat, 248. [in Russian].

[4] Avrov, V.Ja. (1964). O genezise soljanokupol'nyh struktur Prikaspijskoj vpadiny i osnovnyh principah formirovanija $\mathrm{v}$ nih neftjanyh i gazovyh mestorozhdenij [On the genesis of the salt-domed structures of the Caspian basin and the basic principles of the formation of oil and gas fields in them] Preceedings from Uslovija obrazovanija i osobennosti neftegazonosnosti soljanokupol'nyh struktur - Formation conditions and peculiarities of oil and gas content of saltdomed structures. Perv yj simpozium - the 1st symposium. L'vov. Kiev: Naukova dumka. 105-111. [in Russian].

[5] Ajzenshtadt, G.E.-A. (1964). Osnovnye zakonomernosti formirovanija soljanyh kupolov i zalezhej nefti Prikaspijskoj vpadiny [The main regularities of the formation of salt domes 

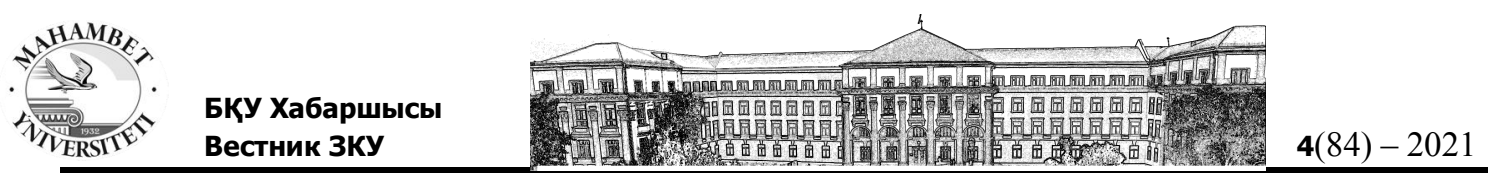

and oil deposits in the Caspian Basin]. Preceedings from Uslovija obrazovanija i osobennosti neftegazonosnosti soljanokupol'nyh struktur - Formation conditions and peculiarities of oil and gas content of salt-dome structures. Perv yj simpozium - the 1st symposium. L'vov. Kiev: Naukova dumka. 58-67. [in Russian].

[6] Bogdanov, A.A. (1934). Osnovy geologicheskogo stroenija Kairovskogo neftjanogo mestorozhdenija [Fundamentals of the geological structure of the Kairovskoye oil field]. Neftjanoe hozjajstvo, 2, 20-23. [in Russian].

[7] Konishhev, V.S. (1984). Sravnitel'aja tektonika oblastej galokineza drevnih platform [Comparative tectonics of halokinesis regions of ancient platforms]. R.G.Gareckij (Ed.). Nauka i tehnika, 190 [in Russian].

[8] Kityk, V.I. (1970). Soljanaja tektonika Dneprovsko-Doneckoj vpadiny [Salt tectonics of the Dnieper-Donetsk depression]. Kiev: Nauk. dumka, 203 [in Russian].

[9] Svitoch, A.A. (1973). Nekotorye cherty stroenija, razvitija, i formirovanija soljanoj struktury Prikaspijskoj vpadiny [Some features of the structure, development, and formation of the salt structure of the Caspian basin] Tektonika i neftegazonosnost' soljanokupol'nyh oblastej SSSR Tectonics and oil and gas content of salt-domed regions of the USSR. III Vsesojuznyj simpozium III All-Union Symposium. Alma-Ata: Izd-vo "Nauka" Kazahskoj SSR, 46-53. [in Russian].

[10]Jackson, M.P.A. \& Seni, S.J. (1984). Atlas of salt domes in the East Texas basin. Austin, Texas: The University of Texas, 102 [in English].

[11]Collins, E.W. (1982). Surfical evidence of tectonic activity and erosion rates, Palestine, Keechi, and Oakwood salt domes, East Texas. Geological Circular 82-3. Bureau of Economic Geology. Austin, Texas, 40 [in English].

[12]Kupfer, D.H. (1981). Structure of Salt in Gulf Coast Domes. /Fifth International Symposium on Salt-Northern Ohio Geological Society. 143-151. [in English].

[13] Talbot, C., Aftabi, P. (2004). Geology and models of salt extrusion at Qum Kuh, Central Iran. Journal of the Geological Society, London. Vol. 161, pp. 321-334. [in English].

[14]Chajkovskij, I.I. (2013). Tipizacija osnovnyh mehanizmov soljanoj tektoniki mira: Verhnekamskoe mestorozhdenie kak jetalon mnogojetapnogo gravitacionnogo skol'zhenija [Typification of the main mechanisms of salt tectonics of the world: Verkhnekamskoe field as a standard of multistage gravitational slip] Vestnik Permskogo nauchnogo centra. 1, 18-37. [in Russian].

[15]Belenickaja, G.A. (2013). Mertvoe more: geologija, proishozhdenie, mify. Chast' 2. Proishozhdenie i istorija razvitija solej, diapirov i rassolov Mertvogo morja [Dead Sea: geology, origins, myths. Part 2. Origin and history of development of salts, diapirs and brines of the Dead Sea]. Prostranstvo i Vremja. 3(13). 130-144. [in Russian].

[16] Samojlova, A.V. \& Obrjadchikov, O.S. (2008). Vlijanie soljanoj tektoniki na obshhie zakonomernosti obrazovanija zalezhej nefti i gaza v vostochnoj i juzhnoj chastjah Prikaspijskoj vpadiny [The influence of salt tectonics on the general patterns of the formation of oil and gas deposits in the eastern and southern parts of the Caspian basin]. Geologija, geofizika i razrabotka neftjanyh i gazovyh mestorozhdenij. 2, 18-20. [in Russian].

[17] Kazancev, Ju.V. \& Kazanceva, T.T. (2007). O mehanizme soljanoj skladchatosti v Predural'skom, Prikaspijskom i Preddoneckom progibah [On the mechanism of salt folding in the Ural, Caspian and Preddonetsk troughs.]. Geologicheskij sbornik. 6, 68-73. [in Russian].

[18] Gorozhanin, V.M. \& Gorozhanina, E.N. (2010). Kriterii prognozirovanija mestorozhdenij nefti i gaza v oblastjah s soljano-kupol'noj tektonikoj (na primere Prikaspija i juga Predural'skogo progiba) [Criteria for predicting oil and gas fields in areas with salt-dome tectonics (on the example of the Caspian Sea and the south of the Cis-Ural trough)]. Geologija, poleznye iskopaemye i problemy geojekologii Bashkortostana, Urala i sopredel'nyh territorij. 8, 198-201. [in Russian]. 

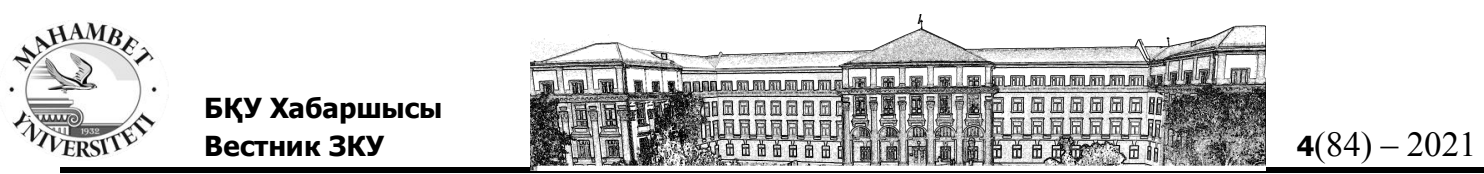

[19]Hudec, M. R. (2011). The Salt Mine: A Digital Atlas of Salt Tectonics / M. R. Hudec, M. P. A. Jackson. Texas: Bureau of Economic Geology, 305 [in English].

[20]Nikolaev, N.I. (1962). Neotektonika i ee vyrazhenie v strukture i rel'efe territorii SSSR [Neotectonics and its expression in the structure and relief of the territory of the USSR]. M., Gosgeoltehizdat, 392[in Russian].

[21]Rozhdestvenskij, A.P. (1971). Novejshaja tektonika i razvitie rel'efa Juzhnogo Priural'ja [The latest tectonics and development of the relief of the Southern Urals]. M., Nauka, 304 [in Russian].

[22] Meshherjakov, Ju.A., Bricyna, M.P. (1954). Geomorfologicheskie dannye o novejshih tektonicheskih dvizhenijah v Prikaspijskoj nizmennosti. Geomorfologicheskie issledovanija v Prikaspijskoj nizmennosti [Geomorphological data on the latest tectonic movements in the Caspian lowland]. Izd. AN SSSR, M., 5-46. [in Russian].

[23] Aristarhova, L.B. (1979). Geomorfologicheskie issledovanija pri poiskah nefti i gaza [Geomorphological studies in the search for oil and gas.]. M., Izd-vo MGU, 152 [in Russian].

[24]Zhuravlev, V.S. (1968). Geomorfologicheskie priznaki vdavlennyh kompensacionnyh mul'd Prikaspijskoj vpadiny. Geomorfologicheskij analiz pri geologicheskih issledovanijah $\mathrm{v}$ Prikaspijskoj vpadine (metody i rezul'taty issledovanij) [Geomorphological signs of depressed compensation troughs of the Caspian Basin. / Geomorphological analysis during geological research in the Caspian basin (methods and results of research)]. L.B.Aristarhova (Ed.). M.: Izd-vo MGU, 77-86. [in Russian].

[25] Sladkopevcev, S.A. (1966). Geomorfologicheskij analiz kak metod detalizacii stroenija i tektonicheskogo razvitija soljanokupol'nyh struktur zapadnoj chasti Podural'skogo plato. Geomorfologicheskie metody pri neftegazopoiskovyh rabotah [Geomorphological analysis as a method of detailing the structure and tectonic development of salt-domed structures in the western part of the Subural plateau. / Geomorphological methods for oil and gas exploration.]. M., "Nedra", 101-103. [in Russian].

[26] Blagovolin, N.S. (1985). Rol' soljanoj tektoniki i grjazevogo vulkanizma v voshodjashhem massoperenose i rel'efoobrazovanii. Geomorfologija [The role of salt tectonics and mud volcanism in ascending mass transfer and relief formation]. 2, 17-27. [in Russian].

[27]Dzens-Litovskij, A.I. (1966). Soljanoj karst SSSR [Salt Karst of the USSR]. L., Nedra, 168. [in Russian].

[28]Korotkevich, G.V. (1970). Soljanoj karst [Salt Karst]. L., Nedra, 256. [in Russian].

[29] Warren, J. (2006). Evaporites: Sediments, Resources and Hydrocarbons. Berlin Heidelberg: Springer-Verlag, 1036 [in English].

[30] Autin, W.J. (2002). Landscape evolution of the Five Islands of south Lousiana: scientific policy and salt dome utilization and management. Geomorphology. V.47. 227-244. [in English].

[31] Lobeck, A.K. (1939). Geomorphology. An Introduction to the Study of Landscapes. New York - London:McGraw-Hill Book Company. 512-517. [in English].

[32] Jahani, S., Callot, J.-P., Frizon de Lamotte D., Letouzey, J. \& Leturmy, P. (2007). The salt diapirs of the Eastern Fars Province (Zagros, Iran): A Brief Outline of their Past and Present. Thrust belts and foreland basins, frontiers in Earth sciences. Ed. By O. Lacombe, J. Lavé, F. Roure, J. Vergés. Berlin, Heidelberg, 289-308. [in English].

[33] Filippi, M., Bruthans, J., Palatinus, L., Zare, M. \& Asadi N. (2011). Secondary halite deposits in the Iranian salt karst: general description and origin. International Journal of Speleology, No 40 (2), 141-162. [in English].

[34] Jaritz, W. (1973). Zur Entstehung der Salzstrukture Nordwestdeutchlands. Geologische jahrbush. Reihe A, Heft 10. Hannover, 78 [in English]. 
[35]Chichagov, V.P. (2014). Geodinamika soljanokupol'nyh struktur rajona Baskuchak Bol'shoe Bogdo.Astrahanskij vestnik jekologicheskogo obrazovanija [Geodynamics of salt-domed structures of the Baskuchak - Bolshoye Bogdo region]. № 4 (30), 24-36. [in Russian].

[36]Kurilenko, V. V. \& Zelenkovskij P. S. (2008). Mestorozhdenie mineral'nyh solej oz. Baskunchak: geologija, osobennosti sovremennogo solenakoplenija, mehanizmy prirodo- i nedropol'zovanija. Vestnik SPbGU [Mineral salt deposit of the lake. Baskunchak: geology, features of modern salt accumulation, mechanisms of nature and subsoil use]. Serija 7. Geologija, geografija. 3, 17-32. [in Russian].

[37]Zarei, M., Raeisi, E. \& Talbot, C. (2012). Karst development on a mobile substrate: Konarsiah salt extrusion, Iran.Geological Magazine, Cambridge University Press, 149 (3), 412-422. [in English].

[38]Nikolaev, V.A., Kopyl, I.V. \& Pichugina, N.V. (1998). Landshaftnyj fenomen soljanokupol'noj tektoniki $\mathrm{V}$ polupustynnom Prijel'ton'e [Pichugina N.V. The landscape phenomenon of salt-dome tectonics in the semi-desert Prielton region]. Vestn. Mosk. un-ta, ser. 5 "Geografija", 2, 1998, 35-39. [in Russian].

[39]Akhmedenov, K.M (2019). Priroda Zapadnogo Kazahstana: obekty prirodnogo nasledija [Nature of Western Kazakhstan: natural heritage objects] Ural'sk: RIC ZKGU im. M.Utemisova, 250 [in Russian].

[40] Sinjakov, V.N., Beljaeva, Ju.L. \& Kuznecova, S.V. (2004). Inzhenerno-geologicheskie i geojekologicheskie problemy stroitel'stva sovremennyh poligonov hranenija tverdyh bytovyh othodov v Zapadnom Prikaspii [Engineering-geological and geoecological problems of construction of modern landfills for storage of solid household waste in the Western Caspian region]. M.: Vysshaja shkola, 220 [in Russian].

[41]Mozer, S.P. (2004). Obosnovanie racional'nyh parametrov tehnologii razrabotki kamennoj soli na mestorozhdenijah kupol'nogo tipa [Ubstantiation of rational parameters of the technology of rock salt development at dome-type deposits] Candidate's thesis. 25.00.22. SanktPeterburg, 25-34. [in Russian].

[42]Nikitin, I.I. \& Russkin, G.A. (1981). Obrazovanie i ischeznovenie ozera Razval [Formation and disappearance of Lake Razval (Sol-Iletsk)]. Izd. Vsesojuz. geogr. obshh-va, t.113, vyp.2, 163-166. [in Russian].

[43]Capina, N. L. (2010). Optimizacija osobo ohranjaemyh prirodnyh territorij v okrestnostjah ozera Baskunchak. Problemy regional'noj jekologii [Optimization of specially protected natural areas in the vicinity of Lake Baskunchak]. 1, 118-123. [in Russian].

[44] Golovachev, I.V. (2010). Karst i peshhery Severnogo Prikaspija [Karst and caves of the Northern Caspian region.]. Astrahan': izdatel'skij dom «Astrahanskij universitet», 215 [in Russian].

\section{Петрищев В.П., Кожевникова Н.В. \\ ҮЙЛЕСІМДІ ТАБИҒАТТЫ ПАЙДАЛАНУ МОДЕЛІН КҰРУДЫН НЕГІЗІ РЕТІНДЕ ТУЗДЫ-КУМБЕЗДІ АЙМАҚТАРДЫН ЛАНДШАФТЫҚ ГЕОЖУЙЕЛЕРІН ҚАЛЫПТАСТЫРУ ФАКТОРЛАРЫН ТАЛДАУ}

Андатпа. Тұз күмбезді ландшафтогенез туралы қазіргі көзқарастар, ең алдымен, ландшафтық геожүйелердің өте жоғары морфоқұрылымдық ерекшелігін тудыратын тұз тектоникасының экзогенездің әртүрлі факторларымен өзара әрекеттесуінің аймақтық модельдерін анықтауда көрінеді. Қазіргі уақытта тұз күмбезді ландшафтогенезге қатысты ең маңызды ғылыми бағыттар төрт негізгі бағытқа қатысты. Біріншісі, тұзды күмбездің үстіндегі ландшафттардың қалыптасу модельдерін құру үшін баға жетпес маңызы бар тұзды күмбезді тектогенез саласындағы түпнұсқа идеялар мен тұжырымдамаларға қатысты. Екіншісі, тұз күмбезді процестердің геоморфологиялық көрінісі мәселелерінің дамуымен байланысты. Үшінші бағыт - ландшафтық ғылым. Ол тұзды құрылымдардың ландшафтық көріністерін көрсететін зерттеулерді біріктіреді. Төртінші бөлім жер қойнауын пайдалану 


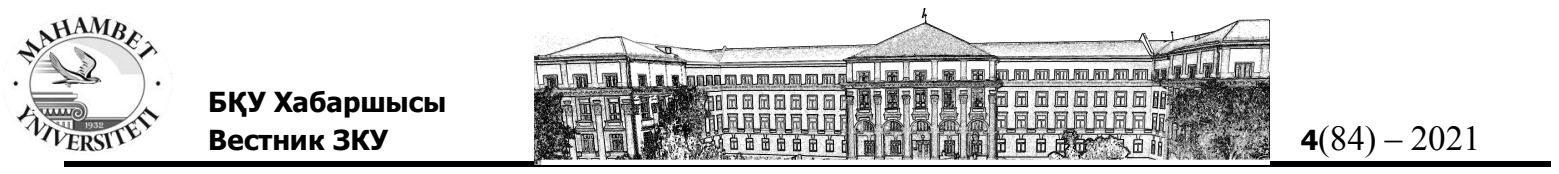

объектілері ретінде де, рекреациялық-туристік және табиғат қорғау мақсатында да тұз күмбезді геожүйелерді пайдаланудың қолданбалы аспектілерін көрсетеді. Эвапориттермен байланысты ландшафттарды зерттеуде ерекше назар олардағы асыл металдардың шоғырлану ықтималдығымен байланысты. Бұл бағыт Каспий маңы-Орал маңы тұз күмбезді бассейні шегінде, оның ішінде Қазақстан Республикасы шегінде болашақты болып табылады. Сондайақ, көбінесе беймәлім факт болып табылатын тұзды тектониканың мелиорациялық рөлі. Каспий маңы ойпатының тұзды күмбездері көптеген ерекше қорғалатын табиғи аумақтарды, оның ішінде Қазақстан Республикасында ұйымдастырудың негізі болып табылады.

Кілт сөздер: тұзды тектоника; галокинез; диапир; кепрок; эвапоритті экструзия; рельефтің морфоқұрылымдық түрлері; тұзды карст; ландшафтық геожүйелер; ландшафтогенездің аймақтық модельдері; кендену; мелиорация; геопарк; спелеотерапия; минералды балшық.

\section{Petrishchev V.P., Kozhevnikova N.V. \\ ANALYSIS OF FACTORS OF FORMATION OF LANDSCAPE GEOSYSTEMS OF SALT DOME REGIONS AS A BASIS FOR BUILDING A MODEL OF HARMONIOUS NATURE MANAGEMENT}

Annotation. Modern views on salt dome landscape genesis are manifested primarily in the identification of regional models of interaction of salt tectonics with various factors of exogenesis, which causes an extremely high morphostructural originality of landscape geosystems. Currently, the most important scientific directions in relation to salt dome landscape genesis concern four main directions. The first concerns original ideas and concepts from the field of salt dome tectogenesis, which is invaluable for constructing models of the formation of landscapes over salt domes. The second is connected with the development of problems of geomorphological manifestation of salt dome processes. The third direction is landscape studies proper. It combines studies reflecting landscape manifestations of salt structures. The fourth section reflects the applied aspects of the use of salt dome geosystems as subsurface use objects, as well as for recreational and tourist purposes and environmental purposes. Particular attention in the study of landscapes associated with evaporites is associated with a high probability of concentration of precious metals in them. This direction is promising within the Caspian-Pre-Ural slanokupolny basin, including within the Republic of Kazakhstan. Also a little-known fact is the reclamation role of salt tectonics. The salt domes of the Caspian Basin are the basis for the organization of numerous specially protected natural areas, including in the Republic of Kazakhstan.

Keywords: salt tectonics; halokinesis; diaper; keprok; evaporite extrusion; morphostructural types of relief; salt karst; landscape geosystems; regional models of landscape genesis; mineralization; reclamation; geopark; speleotherapy; mineral mud. 